that there has been a significant change in policy since 1936, when Levine recommended a period of six to eight weeks in bed, with an appropriate convalescent period. Alternatively, it is possible that there is an increasing occurrence or recognition of milder cases.

While most would acknowledge the considerable psychological benefits which are seen in a patient who is able to resume work, there are very few data concerning the physical effects of resumption of work, and it is impossible to answer the oftput questions, "Will I do myself any harm if I go back to work?" or "Should I have another month's rest from work?" The data presented in this series do not provide an answer to these questions except with respect to the mortality (the crudest index) which compares favourably with that recorded in doctors (Morris, Heady, and Barley, 1952; McMichael and Parry, 1960)-the mortality at one year is $4.2 \%$, compared with $4 \%$ of the doctors (who survived the first month after infarction), and at three years is $14 \%$, compared with $10 \%$ in the doctors' series.

Cook, Tuttle, and Kodlin (1962) report from a cardiac workevaluation centre an attempt to establish whether work had any effects on the progress of heart disease. They graded the work capacity of their patients into five categories ranging from normal capacity to confinement to bed. By comparing their assessment at the initial visit with the actual work being carried out when the patients were seen at six-monthly intervals they were able to classify the men into those who complied with the original advice, those who did more than recommended, and those who did less. The mortality of patients suffering from " atherosclerotic heart disease" showed a gradient from $9 \%$ in those who did excessive work, to $5 \%$ in those who complied with advice, and to $3 \%$ in those who did less work than advised. Further studies are needed to confirm if hard work has any adverse effect on those who have suffered from cardiac infarction.

The possible role of psychological stresses has not been considered as it was not possible to measure them.

\section{Summary and Conclusions}

The return to work of 212 men under 60 years of age who have survived one episode of cardiac infarction showed that
$55 \%$ were back at work within three months and $82 \%$ within six months.

The major changes in employment "status" had generally been achieved within six months of the initial cardiac infarction, and the various employment subgroups at this stage were therefore studied more closely. (a) Part-time work was usually a temporary phase which was ultimately followed by a return to full-time work. (b) A change of job was more common in those in social classes IV and $\mathrm{V}$ and those normally undertaking active or heavy work. (c) A review of the social class, physical activity of work, and severity of initial infarction of the few men who were not at work at six months (and who had not suffered any further episodes of cardiac infarction) did not show any obvious distinguishing features. (d) Study of a sample of those who resumed full-time work within six months indicated that while the majority tended to take it easier than formerly they were still doing a reasonable job of work and were not being "carried" by their employers.

The death rate in the first three years after the initial infarction did not suggest that the high rate of return to work had any adverse effect.

The effects of heavy manual work and of mental stress on the progress of men who have suffered from myocardial infarction are still largely speculative.

I am grateful to Dr. K. P. Ball, Professor J. N. Morris, and Dr. J. A. Heady for their advice and encouragement received while carrying out this study.

\section{REFERENCES}

Bronstein, L. H. (1959). In Work and the Heart, edited by F. F. Rosenbaum and E. L. Belknap. Hoeber, New York.

Cole, D. R., Singian, E. B., and Katz, L. N. (1954). Circulation, 9, 321. Cook, W. L., Tuttle, W. B., and Kodlin, D. (1962). F. occup. Med., 4, 411.

Crain, R. B., and Morris, E. M. (1956). N.Y. St. F. Med., 56, 2238. Levine, S. A. (1936). Clinical Heart Disease. Saunders, Philadelphia. McMichael, J., and Parry, E. H. O. (1960). Lancet, 2, 991.

.

Morris, J. N., Heady, J. A., and Barley, R. G. (1952). Brit. med. F., 1, 503 .

Raffle, $P$.

Lancet, 2, 1053.
Papp, C., and Shirley Smith, K. (1951). Brit. med. F., 1, 1471.

\title{
Effect of Propranolol (Inderal) in Angina Pectoris : Preliminary Report
}

\author{
J. HAMER,* M.D., M.R.C.P. ; T. GRANDJEAN,* M.D. ; L. MELENDEZ,* M.D. ; G. E. SOWTON,* M.B., M.R.C.P.
}

Brit. med. F., 1964, 2, 720-723

The increase in the force of ventricular contraction when the cardiac sympathetic nerves are stimulated suggests that sympathetic activity may be an important determinant of the response of the heart to exercise (Rushmer, Smith, and Franklin, 1959 ; Sarnoff and Mitchell, 1961). However, the improvement in exercise tolerance that follows sympathectomy in patients with angina pectoris (Apthorp, Chamberlain, and Hayward, 1954) indicates that the increased ventricular contractility produced by sympathetic stimulation may be undesirable when

* From. the Institute of Cardiology and the National Heart Hospital, London. myocardial blood-flow is restricted. The cardiac sympathetic system consists of beta-adrenergic receptors (Ahlquist, 1948), which are specifically blocked by pronethalol (Black and Stephenson, 1962). There is evidence that this drug is helpful in angina pectoris (Dornhorst and Robinson, 1962 ; Alleyne et al., 1963 ; Apthorp et al., 1964), but its use has been restricted by undesirable side-effects (Paget, 1963). The recent introduction of a new analogue (Fig. 1) without these drawbacks (Black, Crowther, Shanks, Smith, and Dornhorst, 1964) has allowed fresh assessment of the response to beta-adrenergic blockade. A standardized exercise-tolerance test has been used to determine 
the response of patients with angina pectoris to this drug, and to act as a guide for the selection of patients suitable for prolonged treatment.<smiles>CC(C)NCC(O)C1CCCCCC1(C)OCCO</smiles><smiles>CC(C)NCC(O)C1CCC2CCCCC2C1</smiles><smiles>CC(C)NCC(O)COC1CCCC2CCCCC21</smiles>

FIG. 1.-Structural formulae of pronethalol and propranolol compared with isoprenaline.

\section{Methods}

Twenty patients with a clear history of angina pectoris have been studied (Table I). All were experiencing repeated episodes of angina of effort during their habitual daily activities. The severity of angina pectoris was assessed as slight, moderate, severe, or gross on the basis of effort tolerance as suggested by Wood (1956). Patients with angina at rest or on slight exertion were excluded from the study, as were those with any evidence of left ventricular failure. Electrocardiographic abnormalities were present at rest in 12 subjects. The nature of the test was explained to the patients and their agreement obtained before the study was begun.

\begin{tabular}{|c|c|c|c|c|c|c|}
\hline $\begin{array}{l}\text { Case } \\
\text { No. }\end{array}$ & Age & Sex & $\begin{array}{c}\text { Angina } \\
\text { for }>1 \\
\text { Year }\end{array}$ & $\begin{array}{c}\text { Severity } \\
\text { (grade } \\
1-4)\end{array}$ & $\begin{array}{c}\text { Casual } \\
\text { B.P. }\end{array}$ & $\begin{array}{l}\text { Abnormal } \\
\text { E.C.G. } \\
\text { at Rest }\end{array}$ \\
\hline \multicolumn{7}{|c|}{ Group $A$} \\
\hline $\begin{array}{l}1 \\
2 \\
3 \\
4 \\
5 \\
6 \\
7 \\
8\end{array}$ & $\begin{array}{l}60 \\
50 \\
50 \\
54 \\
67 \\
57 \\
50 \\
56\end{array}$ & $\begin{array}{l}M \\
M \\
M \\
M \\
M \\
M \\
M \\
F\end{array}$ & $\begin{array}{l}+ \\
+ \\
+ \\
0 \\
+ \\
0 \\
+ \\
+\end{array}$ & $\begin{array}{l}2 \\
2 \\
2 \\
2 \\
2 \\
1 \\
3 \\
2\end{array}$ & $\begin{array}{l}140 / 80 \\
150 / 90 \\
130 / 80 \\
135 / 80 \\
120 / 80 \\
120 / 70 \\
130 / 80 \\
165 / 90\end{array}$ & $\begin{array}{l}+ \\
+ \\
+ \\
0 \\
+ \\
0 \\
+ \\
+\end{array}$ \\
\hline \multicolumn{7}{|c|}{ Group $B$} \\
\hline $\begin{array}{r}9 \\
10 \\
11 \\
12 \\
13\end{array}$ & $\begin{array}{l}59 \\
53 \\
56 \\
48 \\
56\end{array}$ & $\begin{array}{l}M \\
M \\
M \\
M \\
M\end{array}$ & $\begin{array}{l}+ \\
0 \\
+ \\
+ \\
+\end{array}$ & $\begin{array}{l}1 \\
2 \\
1 \\
1 \\
3\end{array}$ & $\begin{array}{l}150 / 80 \\
165 / 105 \\
150 / 80 \\
120 / 80 \\
170 / 100\end{array}$ & $\begin{array}{l}0 \\
+ \\
+ \\
+ \\
+\end{array}$ \\
\hline \multicolumn{7}{|c|}{ Group $C$} \\
\hline $\begin{array}{l}14 \\
15 \\
16 \\
17 \\
18 \\
19 \\
20\end{array}$ & $\begin{array}{l}50 \\
64 \\
56 \\
46 \\
52 \\
49 \\
41\end{array}$ & $\begin{array}{c}M \\
F \\
F \\
M \\
F \\
F \\
M\end{array}$ & $\begin{array}{l}+ \\
0 \\
+ \\
0 \\
+ \\
+ \\
+\end{array}$ & $\begin{array}{l}1 \\
1 \\
1 \\
2 \\
2 \\
2 \\
1\end{array}$ & $\begin{array}{l}135 / 80 \\
155 / 90 \\
165 / 85 \\
140 / 75 \\
150 / 80 \\
165 / 90 \\
120 / 80\end{array}$ & $\begin{array}{l}0 \\
0 \\
0 \\
0 \\
+ \\
0 \\
+\end{array}$ \\
\hline
\end{tabular}

The patients were exercised in the sitting position on a Schönander-Elema bicycle ergometer (Holmgren and Mattsson, 1954), which maintains a constant load with wide variations in the rate of pedalling. Changes in the electrocardiogram during exercise were followed by a modified $\mathrm{CR}_{5}$ lead with the remote electrode on the right shoulder. Exercise was begun at 60 cycles a minute and a work level of 100 metre-kilopond (mkp.)/min. (16 watts). The load was increased at six-minute intervals by $200 \mathrm{mkp}$./min. (33 watts). The patients were warned that they must stop bicycling at the onset of angina, but were encouraged to continue exercise to the limit of tolerance if no angina occurred.

The electrocardiogram was recorded at two-minutes intervals, and more often as the limit of exercise tolerance was approached to detect changes indicating myocardial ischaemia. In one patient exercise was stopped because of electrocardiographic changes in the absence of symptoms. The angina produced during the test resembled the patient's natural attacks but occurred under close observation with electrocardiographic control and was quickly terminated by stopping the exercise. In six patients the blood-pressure was recorded by sphygmomanometer at each work level. The patients were then allowed to rest for 30 minutes and the test was repeated 15 to 20 minutes after the intravenous injection of $5 \mathrm{mg}$. of propranolol (Inderal). In five patients the test was repeated after two weeks' oral therapy at a dose of 20 or $30 \mathrm{mg}$. of propranolol t.d.s.

The graduated increase in work during the test has the advantage that the limit of exercise tolerance is reached at a relatively high work level and is usually clear cut. In spite of the clinical evidence of angina pectoris many patients were limited by fatigue rather than chest pain. The limiting factor in each patient was recorded before and after the drug. The total work performed in each test was calculated, and the heart rate was obtained from the electrocardiogram at rest and after two, four, and six minutes at each work level (Fig. 2). Analysis of the



FIG. 2-Changes in pulse rate during the standardized exercise-tolerance test before and after betaadrenergic blockade in a patient with angina pectoris. The patient exercised continuously on a bicycle ergometer and the work load was increased at sixminute intervals. The heart rate rose as the work was increased but became stable towards the end of each six-minute period. The heart rate was slower at all levels of exercise after beta-adrenergic blockade.

electrocardiographic changes during exercise was confined to measurement of ST segment depression; changes in the J point were disregarded.

\section{Results}

Thirteen of the 20 patients were limited by angina pectoris in the control exercise test. After the drug angina was the limiting factor in only eight subjects. The patients were divided into three groups on the basis of this response (Table II). The changes in each subject are shown in Table III. The bradycardia produced by the drug was similar in each group, the average reduction in rate being $17 \%$ after six minutes at the maximum work level attained by each subject both before and after the drug (Fig. 3). In Case 8, included in group A (Table II), exercise was stopped before the limit had been reached because of ST segment depression in the electro- 
cardiogram without pain both in the control test and after the drug, and no satisfactory estimate of exercise tolerance could be made.

TABLE II.-Clinical Features in the Three Groups of Patients

\begin{tabular}{|c|c|c|c|c|c|c|c|c|}
\hline \multirow[b]{2}{*}{$\begin{array}{l}0.9 \\
0 \\
0\end{array}$} & \multirow[b]{2}{*}{  } & \multicolumn{2}{|c|}{ Limiting Factor } & \multirow[b]{2}{*}{ 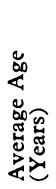 } & \multirow[b]{2}{*}{  } & \multirow{2}{*}{ 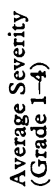 } & \multirow[b]{2}{*}{ 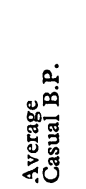 } & \multirow{2}{*}{ 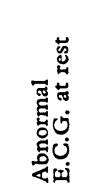 } \\
\hline & & Control & $\begin{array}{l}\text { After } \\
\text { Drug }\end{array}$ & & & & & \\
\hline $\begin{array}{l}\mathbf{A} \\
\mathbf{B} \\
\mathbf{C}\end{array}$ & $\begin{array}{l}8 \\
5 \\
7\end{array}$ & $\begin{array}{l}\text { Angina* } \\
\text { Angina } \\
\text { Fatigue }\end{array}$ & $\begin{array}{l}\text { Angina* } \\
\text { Fatigue } \\
\text { Fatigue }\end{array}$ & $\begin{array}{l}56 \\
54 \\
51\end{array}$ & $\begin{array}{l}6(75 \%) \\
4(80 \%) \\
5(71 \%)\end{array}$ & $\begin{array}{l}2.0 \\
1.6 \\
1.4\end{array}$ & $\begin{array}{l}136 / 81 \\
151 / 89 \\
147 / 83\end{array}$ & $\begin{array}{l}6(75 \%) \\
4(80 \%) \\
2(29 \%)\end{array}$ \\
\hline
\end{tabular}

* Includes one patient stopped because of ST segment depression without pain

TABLE III.-Exercise Tolerance Before and After Beta-adrenergic Blockade in 20 Patients with Angina Pectoris

\begin{tabular}{|c|c|c|c|c|c|c|}
\hline \multirow{2}{*}{$\begin{array}{l}\text { Case } \\
\text { No. }\end{array}$} & \multicolumn{3}{|c|}{ Total Work (mkp) } & \multicolumn{3}{|c|}{ Heart Rate on Exercise* } \\
\hline & Control & |After Drug & $\%$ Change & Control & $\mid$ After Drug| & $\%$ Change \\
\hline \multicolumn{7}{|c|}{ Group $A$} \\
\hline $\begin{array}{l}1 \\
2 \\
3 \\
4 \\
5 \\
6 \\
7 \\
8\end{array}$ & $\begin{array}{c}1,250 \\
3,100 \\
2,900 \\
5,150 \\
850 \\
5,100 \\
900 \\
-\end{array}$ & $\begin{array}{c}3,050 \\
3,150 \\
4,400 \\
6,800 \\
1,800 \\
8,100 \\
1,050 \\
-\end{array}$ & $\begin{array}{r}+142 \\
+1 \\
+52 \\
+32 \\
+112 \\
+59 \\
+18 \\
-\end{array}$ & $\begin{array}{r}93 \\
115 \\
98 \\
112 \\
120 \\
94 \\
98 \\
133\end{array}$ & $\begin{array}{r}77 \\
107 \\
84 \\
99 \\
100 \\
77 \\
88 \\
105\end{array}$ & $\begin{array}{r}-18 \\
-7 \\
-15 \\
-12 \\
-17 \\
-18 \\
-10 \\
-21\end{array}$ \\
\hline \multicolumn{7}{|c|}{ Group B } \\
\hline $\begin{array}{r}9 \\
10 \\
11 \\
12 \\
13\end{array}$ & $\begin{array}{l}7,000 \\
2,650 \\
3,500 \\
7,150 \\
2,400\end{array}$ & $\begin{array}{l}8,140 \\
2,830 \\
3,650 \\
6,300 \\
3,400\end{array}$ & $\begin{array}{r}+17 \\
+7 \\
+5 \\
-12 \\
+42\end{array}$ & $\begin{array}{l}115 \\
122 \\
119 \\
150 \\
104\end{array}$ & $\begin{array}{r}94 \\
107 \\
107 \\
124 \\
93\end{array}$ & $\begin{array}{l}-18 \\
-12 \\
-10 \\
-18 \\
-11\end{array}$ \\
\hline \multicolumn{7}{|c|}{ Group C } \\
\hline $\begin{array}{l}14 \\
15 \\
16 \\
17 \\
18 \\
19 \\
20\end{array}$ & $\begin{array}{r}4,400 \\
1,600 \\
3,050 \\
13,000 \\
2,900 \\
6,800 \\
4,700\end{array}$ & $\begin{array}{r}6,050 \\
1,500 \\
3,100 \\
11,600 \\
3,150 \\
8,100 \\
5,300\end{array}$ & $\begin{array}{r}+38 \\
-6 \\
+1 \\
-11 \\
+9 \\
+19 \\
+12\end{array}$ & $\begin{array}{l}141 \\
148 \\
134 \\
180 \\
150 \\
115 \\
137\end{array}$ & $\begin{array}{r}109 \\
107 \\
110 \\
145 \\
125 \\
88 \\
109\end{array}$ & $\begin{array}{l}-23 \\
-28 \\
-18 \\
-20 \\
-17 \\
-24 \\
-20\end{array}$ \\
\hline
\end{tabular}
* After six minutes at the maximum work level reached both before and after the
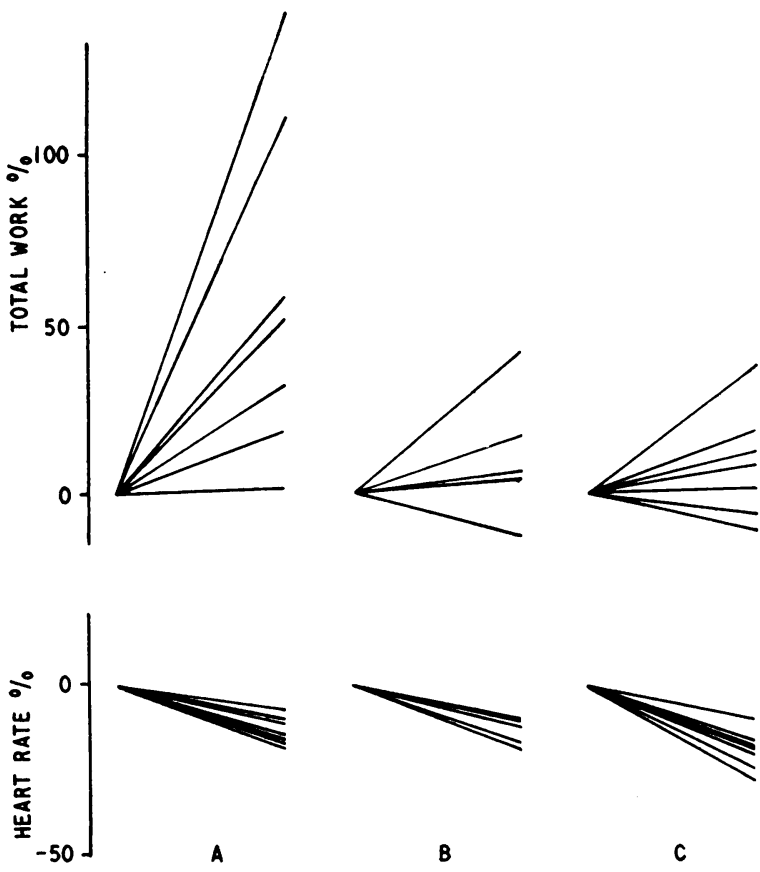

FIG. 3.-Changes in exercise tolerance and pulse rate after beta-adrenergic blockade in 20 patients with angina pectoris. Group A : patients limited by angina before and after the drug. Group A: patients limited by angina before and after the drug. by fatigue after the drug. Group $C$ : patients limited by by fatigue after the drug. Group C: patients limited by
fatigue both before and after the drug. The bradycardia is similar in the three groups, but only patients in Group A show a definite increase in exercise tolerance.
In the remaining seven patients in group $\mathrm{A}$ exercise was limited by angina both before and after the drug. There was a significant increase $(+60 \%)$ in the total work performed after the drug in these patients $(t=3.8, P<0.01)$ (Table IV ; Fig. 3 ), and exercise changes in the electrocardiogram were less frequent and less severe after the drug (Fig. 4). The average increase in exercise tolerance in this group is shown diagrammatically in Fig. 5. The exercise tolerance and heart rate in the control

TABLE IV.-Effect of Beta-adrenergic Blockade on Exercise Tolerance in

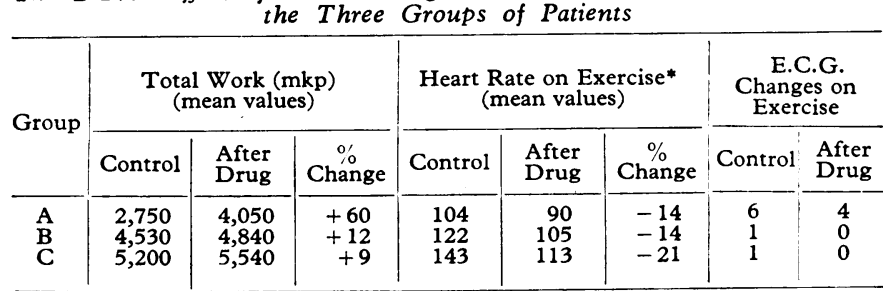
* After six minutes at the maximum work level reached both before and after the drug.

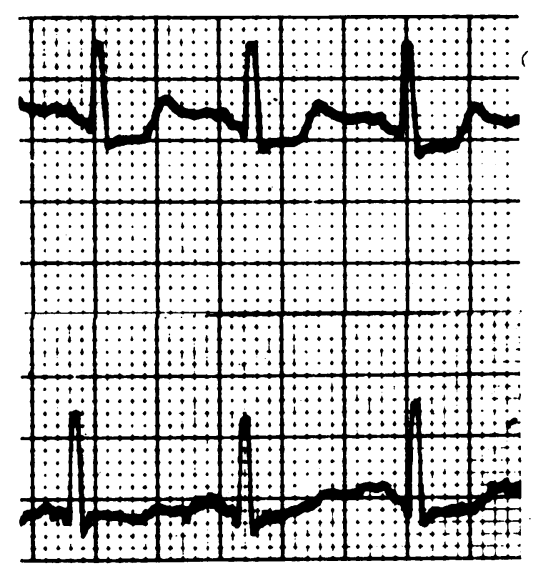

FIG. 4.-Electrocardiogram (lead $\mathrm{CR}_{\mathrm{s}}$ ) in Case 5 after 6.75 minutes' exercise (total work $825 \mathrm{mkg}$.) before (above) and after work 825 mkg.) before (above) and after
(below) beta-adrenergic blockade. The heart rate is slower after the drug and there is less depression of the ST segment.

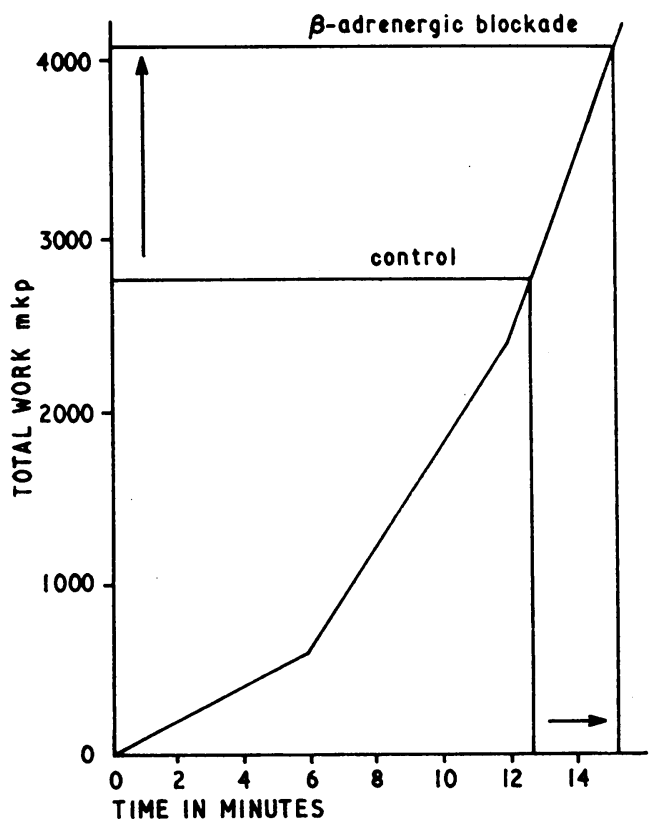

FIG. 5.-Average increase in exercise tolerance in patients limited by angina both before and after patients limited by angina both before and after beta-adrenergic blockade (group A). The work load is increased at six-minute intervals during the test, and the average increase in total work from 2,750
to 4,050 mkp corresponds to a further 2.5 minutes' exercise at $500 \mathrm{mkp} / \mathrm{min}$. (82 watts). 
test tended to be lower in these patients than in the other subjects studied. Group B consists of five patients limited by angina before but not after the drug, and in group $C$ (seven cases) angina was not produced at either test. There was less electrocardiographic evidence of myocardial ischaemia in the last group. No significant change in total work was found after the drug in these two groups, and few patients showed electrocardiographic changes on exercise. No consistent change in blood-pressure was noted in this study.

In five patients the exercise test was repeated after oral treatment for two weeks. Two patients were limited by angina both before and after the drug (group A), and three had angina in the control test but were limited by fatigue after treatment (group B). In each case the limiting factor was the same after oral administration as after intravenous injection of the drug. The changes in heart rate were similar, but in two patients there was less improvement in exercise tolerance after oral treatment (Table V).

TABLE V.-Effects of Oral Therapy on Exercise Tolerance

\begin{tabular}{|c|c|c|c|c|c|c|c|c|c|c|}
\hline \multirow{3}{*}{$\begin{array}{l}\text { Case } \\
\text { No. }\end{array}$} & \multicolumn{5}{|c|}{ Total Work (mkp) } & \multicolumn{5}{|c|}{ Heart Rate on Exercise } \\
\hline & \multirow{2}{*}{ Control } & \multirow{2}{*}{$\begin{array}{l}\text { After } \\
\text { I.V. } \\
\text { Drug }\end{array}$} & \multirow{2}{*}{\begin{tabular}{|l|l} 
After \\
Oral \\
Drug
\end{tabular}} & \multicolumn{2}{|c|}{$\%$ Change } & \multirow{2}{*}{$\begin{array}{l}\text { Con- } \\
\text { trol }\end{array}$} & \multirow{2}{*}{\begin{tabular}{|l|} 
After \\
I.V. \\
Drug
\end{tabular}} & \multirow{2}{*}{\begin{tabular}{|l|} 
After \\
Oral \\
Drug
\end{tabular}} & \multicolumn{2}{|c|}{$\%$ Change } \\
\hline & & & & I.V. & Oral & & & & I.V. & Oral \\
\hline \multicolumn{11}{|c|}{ Group $A$} \\
\hline $\begin{array}{l}3 \\
4\end{array}$ & $\begin{array}{l}2,900 \\
5,150\end{array}$ & $\begin{array}{l}4,400 \\
6,800\end{array}$ & $\left|\begin{array}{l}3,400 \\
6,800\end{array}\right|$ & $\begin{array}{l}+52 \\
+32\end{array}$ & $\begin{array}{l}+17 \\
+32\end{array}$ & $\begin{array}{r}98 \\
112\end{array}$ & $\begin{array}{l}84 \\
99\end{array}$ & $\begin{array}{l}82 \\
98\end{array}$ & $\begin{array}{l}-15 \\
-12\end{array}$ & $\begin{array}{l}-16 \\
-12\end{array}$ \\
\hline \multicolumn{11}{|c|}{ Group B } \\
\hline $\begin{array}{l}11 \\
12 \\
13\end{array}$ & $\begin{array}{l}3,500 \\
7,150 \\
2,400\end{array}$ & $\mid \begin{array}{l}3,650 \\
6,300 \\
3,400\end{array}$ & $\left|\begin{array}{c}3,600 \\
7,500 \\
2,600\end{array}\right|$ & $\begin{array}{r}+5 \\
-12 \\
+42\end{array}$ & $\begin{array}{l}+2 \\
+6 \\
+8\end{array}$ & $\begin{array}{l}119 \\
150 \\
104\end{array}$ & $\begin{array}{r}107 \\
124 \\
93\end{array}$ & $\begin{array}{r}105 \\
120 \\
89\end{array}$ & $\begin{array}{l}-10 \\
-18 \\
-11\end{array}$ & $\begin{array}{l}-12 \\
-20 \\
-14\end{array}$ \\
\hline
\end{tabular}

No untoward effects followed the exercise tests in these patients and there were no symptoms attributable to the drug.

\section{Discussion}

The exercise test used in this study, allowing six minutes at each work level, has been extensively used by other workers (Bevegård, 1963). There is usually little change in heart rate from the fourth to the sixth minute of each phase of the test (Fig. 2), and it seems likely that the patient reaches a stable state at the end of each six-minute period. The total work performed during the test is a useful measure of exercise tolerance; the corresponding change in the duration of exercise is shown in Fig. 5.

The relative slowing of the heart rate on exercise in this study was similar to that found after treatment with pronethalol (Dornhorst and Robinson, 1962; Apthorp et al., 1964). The parenteral dose of propranolol used was approximately onetenth of the effective dose of pronethalol and was similar to that shown to produce effective beta-adrenergic blockade in animals (Black et al., 1964). No side-effects were observed after a single intravenous dose. Oral absorption, however, is probably incomplete (R. Shanks and W. A. M. Duncan, personal communication, 1964), and considerably larger doses were needed to produce an equivalent bradycardia by this route.

Beta-adrenergic blockade reduces the heart rate at all levels of exercise, but Bishop and Segel (1963) and Chamberlain and Howard (1964) have shown that the cardiac output on exercise in the erect position is maintained. The relative bradycardia may improve exercise tolerance in angina pectoris by increasing diastolic flow through the coronary vascular bed. Reduction in contractility of the myocardium may well be an important effect of beta-adrenergic blockade in coronary artery disease, allowing more efficient utilization of the available supply of oxygen (Apthorp et al., 1964), but no evidence to support this suggestion was found in the present study.

The subjective effect of treatment is somewhat counterbalanced in this study by the considerable effort required to perform the test for a second time within an hour. In group $\mathrm{C}$, in which the patients were limited by fatigue in each test, there was little tendency to an increase in exercise tolerance from the therapeutic suggestion of an intravenous injection. The five patients in group B were limited by angina in the control test, but performed similar amounts of work in the second test without angina. Patients in group A were not limited by fatigue either before or after the drug, and the significant increase in total work suggests a beneficial effect from beta-adrenergic blockade.

\section{Summary}

The effect of a new beta-adrenergic blocking agent propranolol (Inderal) in 20 patients with angina pectoris was studied by comparing exercise tolerance on a bicycle ergometer before and after intravenous injection of the drug.

The parenteral dose needed to produce satisfactory blockade, as judged by bradycardia, was about one-tenth of that required in the case of pronethalol. No side-effects were noted after intravenous injection.

The exercise tolerance of the seven patients who were limited by angina pectoris was generally increased after the drug (group A). Five patients limited by angina in the control test had no angina at a similar work level after the drug (group B). Seven patients were limited by fatigue and showed no change in exercise tolerance (group $\mathrm{C}$ ).

This study suggests that beta-adrenergic blockade may be helpful in angina pectoris. Further work is needed to assess the mechanism of improvement in exercise tolerance and to determine the effectiveness of prolonged oral therapy.

We would have been unable to undertake this work without the co-operation of the patients who participated in the study, and we would like to express our appreciation of their help. We are most grateful to Dr. Wallace Brigden, Director of the Institute of Cardiology, for allowing us to study patients under his care. We are indebted to the Pharmaceuticals Division of I.C.I. for the supply of propranolol (Inderal) used in this work.

\section{REFERENCES}

Ahlquist, R. P. (1948). Amer. F. Physiol., 153, 586

Alleyne, G. A. O., Dickinson, C. J., Dornhorst, A. C., Fulton, R M. Green, K. G., Hill, I. D., Hurst, P., Laurence, D. R., Pilkington, T., Prichard, B. N. C., Robinson, B., and Rosenheim, M. L. (1963).
Brit. med. F., 2, 1226 .

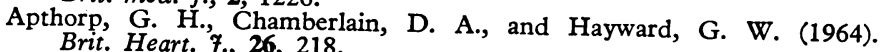

Bevegård, S. (1963). 26, 218 .

Bishop, J M., and. Acta physiol. scand., 57, Suppl. No. 200

Blat. W. , and Segel, N. (1963). F. Physiol., 169, 112 P. horst, A, Crowther, A. F., Shanks, R. G., Smith, L. H., and Dornhorst, A. C. (1964). Lancet, 1, 1080.

- Chamberlain Stephenson, J. S. (1962). Ibid., 2, 311.

Chamberlain, D. A., and Howard, J. (1964). Brit. Heart 7., 26, 213.

6, 137. A., and Mattsson, K-H. (1954). Scand. F. clin. Lab. Invest., Paget, G. E. (1963). Brit. med. F., 2, 1266.

Rushmer, R. F., Smith, O., and Franklin, D. (1959). Circulat. Res., Sarnoff, S.

Wood, P. J., and Mitchell, J. H. (1961). Amer. F. Med., 30, 747 Eyre and Spottiswoode, Diseases of the Heart and Circulation, 2nd ed. 